\title{
Analysis of the Use of Statistical Data in the Formulation of Strategies, Tactics and Evaluation of Football Matches
}

\author{
Muhammad Lintu Aji Prakoso \\ Departement Sport Science \\ Universitas Negeri Yogyakarta \\ Yogyakarta, Indonesia \\ muhammadlintu.2019@student.uny.ac.id
}

\author{
Ria Lumintuarso \\ Departement Sport Science \\ Universitas Negeri Yogyakarta \\ Yogyakarta, Indonesia \\ loemin@yahoo.com
}

\begin{abstract}
This study discussed the use of statistical data in the formulation of strategy, tactics, and evaluation in football matches. This study aimed at describing the use of statistical data in the formulation of strategies, tactics, and evaluations in football matches. A descriptive method was used in this research. The subject of this study were 23 licensed football coaches in Sleman. Sampling in this study using a purposive sampling technique. The data collection technique used in this study was a questionnaire. The data analysis technique used in this study was descriptive statistics. The results showed that the use of statistical data was not optimal due to the absence of tools, the coaches believed more in their intuition when making decisions of tactics, and statistical data was not familiar to many coaches. In determining strategies, tactics, and evaluating matches, the coaches are still limited to using handwritten media. The use of media notes in the form of writing shows that the tools for recording football statistical data have not been able to reach the coaches so that the use of statistical data has not been optimal.
\end{abstract}

Keywords—Statistical data, Strategy, Tactics, Evaluation.

\section{INTRODUCTION}

The developments in sports science are inseparable from the demands of sports to achieve the maximum results. Currently, almost all policies or decisions taken by the experts and executives are based on the results of the analysis and interpretation of data from statistics. Likewise, the mass media use statistics as an entertainment medium to present data in such a way so that the audience can easily understand a match. The fans use statistical data to measure the performance of their favorite players or teams, then debate the rankings among friends or on social media sites [1].

Football already uses statistics as a component that cannot be separated from sports. The close relationship between statistics and sport is because of the large amount of data available on sports such as individual performance [2]. Statistics is the study of data, which is related to collecting, processing, interpreting, and concluding data in numbers [3]. Football match statistics can be used as the material evaluation for coaches to maximize the quality of the team. The purpose of collecting statistical data is to provide an evaluation of team performance during the match [4]. In football matches, there are events that, if collected, will be used as material for the coaches to evaluate and make decisions.

Football is one sport that has the complexity of games and events that are abstract. Soccer performance is very complex, it has many aspects that are difficult to define [5]. The data set is extensive and it includes information for events during a match, including types of passes, tackles, kicks, etc. [6]. Statistical methodology is designed to produce relevant information efficiently about a process from sports data that is generally empirical [7]. Statistical data is information that is empirical if it can be used to analyze the performance of players.

The use of data to predict future performance is less explored yet can provide important information for improving performance [8]. Statistical data will be more meaningful if the information from the results of data collection is analyzed as needed. Information provided by analyzing variations in players' performance incorporating the possible effects of player performance can be a very important contribution to a better understanding of football match performances [9]. This is very important when analyzing sports data because we all know that match results do not depend solely on the outcome of the match or the athlete's skill. In analyzing the match, it does not only depend on the skills of the participants but also luck and randomness of the match [7].

The use of statistical data in football can help the coaches in the process of formulating strategies and tactics and evaluating them. Recent studies have shown that $\pm 40 \%$ of a sample of 46 elite coaches attribute their instincts to the choice of key performance indicators and $\pm 90 \%$ identify that philosophy influences the choice of coaches [10]. Statistical data is used to eliminate intuition, imagination, quick decision making, and the personality of the coaches who are more likely to be associated with winning than principles and processes [11].

The performance analysis should combine the descriptions of players' relationships over time and space, as well as the characterization of play patterns, the complementarity between the two types of measurement provides a promising approach for coaches [12]. The statistics recording of the performance in football is based on the players' activity in a match. The terms of performance activities performed by players and teams during a match such as passes, shots, chances, field areas, 
defensive action, duels, and goalkeeping [13]. Statistical data in football can provide data related to player actions that can be used as information about team performance.

Current performance analysis adopts a quantitative operational approach that focuses on recording the frequency of actions and movement patterns of players [12]. Match analysis is based on statistical data which refers to objectively recording and checking the activities of one player or a team. Statistical data for match analysis refers to the recording and objective examination of behavioral events that are focused on players' activity [14]. A game statistic is related to players' actions which can provide valuable information on the team's successful and unsuccessful performance during the match [4].

The use of statistical data in football can help coaches in the process of formulating strategies and tactics. A strategy is concerned before the game started and tactics relate during the match. [15]. Coaches can identify performance features to change behavior based on information gathered from past performances (statistical data) [16]. The data action player during the match can form the basis for the coaches to formulate strategies and tactics for training programs and preparation for the next match. An effective design for the training program about the preparation for upcoming matches, together with information from matches [12].

The step-in describing the use of football statistical data involves the coaches' activities associated with the match. It means by describing in depth the coaches' behavior during the match, it will be possible to see and assess the use of statistical data optimally or not. Therefore, this study aims to analyze the use of match statistical data by coaches. The use of match statistical data can be seen from the process of strategy formulation, tactics/decision making, and evaluation carried out by the coaches. The use of media used by the coaches as a tool is also considered in this study. In this study, the coaches will describe what common media are used and what the media might be the coaches used. The choice of effective and efficient media can assist coaches in collecting statistical data so that the data presented can be accurate.

\section{METHOD}

This research used descriptive quantitative research methods. The sampling technique in this study was using a purposive sampling technique. This research will find out about the use of football statistical data in the formulation of strategies, tactics, and evaluation of football matches. The sample collection technique in this study used a purposive sampling technique with a total sample of 23 coaches in Sleman. The data source of the sampling technique is based on certain considerations [17]. The sample chosen is based on licensed football coaches. The selection of licensed coaches is because the coaches are considered to have extensive insight into coaching studies [18].

The data collection technique used in this study was a questionnaire. The instrument used was a questionnaire in the form of questions and reasons to be answered by the respondents. Questionnaires were used to obtain information from respondents about the use of statistical data in the formulation of strategies, tactics, and evaluation of football matches. The data analysis technique in this study used descriptive statistics to describe the object under study [17].

\section{RESULT AND DISCUSSION}

The result of this study is a component of the use of statistical data for coaches. There are 4 question indicators in this aspect that consists of the use of football statistics, the coaches' views on statistical data, the use of tools for statistical data collection, and the views of the coach if the statistical data collection tool is android based. The following is the recapitulation of the research on the components of using statistical data for coaches:

TABLE 1. RECAPITULATION ON THE COMPONENTS OF USING STATISTICAL DATA

\begin{tabular}{|c|l|l|}
\hline No & \multicolumn{2}{|c|}{ Question Analysis } \\
\hline 1 & $\begin{array}{l}30,4 \% \text { the coach collects } \\
\text { statistical data }\end{array}$ & $\begin{array}{l}69,6 \% \text { the coach does not collect } \\
\text { statistical data }\end{array}$ \\
\hline 2 & $\begin{array}{l}100 \% \text { the coach said statistics } \\
\text { are important }\end{array}$ & $\begin{array}{l}0 \% \text { the coach said the statistics } \\
\text { were not important }\end{array}$ \\
\hline 3 & $\begin{array}{l}26,1 \% \text { the coach takes notes } \\
\text { using the tools }\end{array}$ & $\begin{array}{l}73,9 \% \text { of coaches note without } \\
\text { using the tools }\end{array}$ \\
\hline 4 & $\begin{array}{l}100 \% \text { the coach agrees with } \\
\text { an Android-based statistical } \\
\text { recording tool }\end{array}$ & $\begin{array}{l}\text { 0\% the coach disagrees with } \\
\text { Android-based statistical } \\
\text { recording tools }\end{array}$ \\
\hline
\end{tabular}

In the question about the use of football statistics, the results show that $30.4 \%$ of coaches have not used and $69.6 \%$ have used. Coaches who have not used or collected statistical data because they think they are familiar and still have limited tools to use. Meanwhile, coaches who have used it think that statistical data can help them to see players' performance.

The results of the coaches' view of statistical data in football show that $100 \%$ of coach say statistical data is important in football. The coaches consider that the statistical data is a reference for player performance which can be used as a benchmark for the coach's program design.

The use of statistical recording tools used by the coaches showed that $26.1 \%$ of coaches did not use tools and $73.9 \%$ of coaches used tools. The coaches have not used it because there is no tool used to record statistical data. While the tools used for coaches who have used are in the form of paper.

The question regarding statistical data recording tools using Android shows that $100 \%$ of the coaches strongly agree with the android application that is used to record match statistics. The coaches assume that Android is easier and more flexible to use.

The results of this study with a match component, questions in this aspect consist of 6 question indicators as seen from the match strategy, tactics or decision making during the match, and evaluation after the match. The following is the recapitulation of the competition component research for coaches: 
TABLE 2. RECAPITULATION ON THE COMPONENTS OF THE MATCH

\begin{tabular}{|l|l|l|l|}
\hline No. & \multicolumn{3}{|c|}{ Question Analysis } \\
\hline 1 & $\begin{array}{l}47,8 \% \text { of the coach developed } \\
\text { strategies based on statistical } \\
\text { data }\end{array}$ & $\begin{array}{l}52,2 \% \text { the coach did not develop } \\
\text { strategies based on statistical data }\end{array}$ \\
\hline 2 & $\begin{array}{l}82,6 \% \text { the coach strategizes in } \\
\text { writing }\end{array}$ & $\begin{array}{l}17,4 \% \text { the coach strategizes the } \\
\text { unwritten }\end{array}$ \\
\hline 3 & $\begin{array}{l}39,1 \% \text { of the coaches formulate } \\
\text { tactics or decision making based } \\
\text { on statistical data }\end{array}$ & $\begin{array}{l}60,9 \% \text { of the coaches do not make } \\
\text { tactics/decisions based on } \\
\text { statistical data in }\end{array}$ \\
\hline 4 & $\begin{array}{l}34,8 \% \text { of the coaches formulate } \\
\text { tactics/decision making in } \\
\text { writing }\end{array}$ & $\begin{array}{l}\text { 65,2\% of the coaches formulate } \\
\text { tactics/decision making in } \\
\text { unwritten }\end{array}$ \\
\hline 5 & $\begin{array}{l}47,8 \% \text { of the coach compile } \\
\text { evaluations based on statistical } \\
\text { data }\end{array}$ & $\begin{array}{l}52,2 \% \text { the coach did not compile } \\
\text { evaluations based on statistical } \\
\text { data }\end{array}$ \\
\hline 6 & $\begin{array}{l}87 \% \text { the coach prepares a } \\
\text { written evaluation }\end{array}$ & $\begin{array}{l}13 \% \text { the coach compiles an } \\
\text { unwritten evaluation }\end{array}$ \\
\hline
\end{tabular}

In football, several important components are carried out by the coach during the match. The formulation of a match strategy for the players and the team is the first step taken by the coach. Strategies can be used by coaches to improve the development of players and teams as well as the technical skills that have been learned [19]. From a match or practice game, the coach must then define the problem and the strategy to be used [18].

From the research results regarding the use of statistical data in formulating strategies, the results showed that $47.8 \%$ used statistical data as a reference for match strategy planning and $52.2 \%$ did not use statistical data as a reference for match strategy planning. The coach argues that the use of statistical data is the result of the performance of the team or the opposing team which can be used as a reference for developing match strategies. Meanwhile, coaches do not develop strategies based on statistical data because they are not familiar with statistical data recording and have limited tools for statistical data collection.

The use of statistical data can help the coach plan strategy before the match. Statistical data can help provide conclusions from the results of previous matches and an examination of the strategies being used [20]. The analysis of statistical data for football strategy highlights that the ability to create opportunities to shoot a shot on goal increases the likelihood of scoring and, winning matches [21]. Statistical data describes the individual behavior of both teams' players in many matches, these statistics can be useful for coaches to improve daily training and strategy in matches [22].

Tactics are a way for coaches to make decisions when a match takes place. Tactics consist of individual tactics, unit tactics, and team tactics. During the match, the coach prepares tactics to make decisions regarding the performance of players and opponents. Coaches usually try to use timely substitutions to reduce fatigue across the team or in an attempt to make changes to tactics [23]. Team adaptability can include the ability of the team to adapt tactics and formations to specific situations in a match [5]. Adaptation to the game is needed if the strategy formulated cannot work and a change in formation or substitutions is needed.
The use of statistical data for the preparation of tactics or decision making during the match shows the results of $39.1 \%$ of decision making based on statistical data and $60.9 \%$ of decision making not based on statistical data. The coaches argue that they use statistical data for decision making because the statistical data is more accurate and detailed based on activities that occur in the field. Meanwhile, coaches who do not use statistical data for decision making because they are more confident in their intuition and the conditions of the game change quickly so that decision making must be fast.

The use of statistical data can help the coaches in making decisions. The contextual factors of the coach influence team and player decisions and the behavior that results from them [16]. Match tactics are influenced by the scoreline in football and teams and players change their playing styles during the match [24]. The coach who analyses the performance of the opposing party will use the data to identify ways to counter the team's strengths and exploit their weaknesses [25]. With statistical data evidence about how individuals show abilities during a match, it is useful for coaches to make decisions [5]. The use of statistical data in decision making during the match can minimize the coach's subjectivity. Simple statistical data can provide a very complete picture of individual performance objectively to measure individual performance against the team [26].

Match evaluation is carried out after the end of the match. Concerning evaluations from players, themselves, and also the match, the coach can then return to planning training [18]. Evaluation is carried out by the coach to provide feedback on the performance made by the players. Coaches can identify players' performance to change future behavior based on information gathered from past performances (previous matches) [16].

The results of the questions regarding the use of statistics as material for match evaluation were $47.8 \%$ of coaches evaluated matches based on statistical data, and $52.2 \%$ did not evaluate based on statistical data. The coach argues that the use of statistical data to evaluate matches is because statistical data is data on player activity during the match and the evaluation becomes more detailed. Meanwhile, the coach does not use statistical data because there is no tool for data collection and believes more in a personal approach to players.

The match statistics are material for evaluation for the coach to improve the quality of the team maximally. The purpose of collecting statistical data is to provide an evaluation of team performance during the match [4]. A statistical approach can be used to identify key performance indicators in soccer. This approach allows more objective information to be provided to coaches and performance analysts to evaluate their team's post-match performance and to take into account the strengths of opponents when planning training sessions and upcoming match tactics [27]. Therefore coaches can design training or pre-match sessions based on the results of previous matches.

Statistical data in football is a collection of activities carried out by players and teams during matches. The use of statistical data is important for coaches because these statistical data can contain player performance during the match. Match statistics 
can provide an overview of a match and as a material for coaches to evaluate for coaches and develop an effective strategy [28]. Statistical data can help coaches understand the concept and describe a match.

The results of the questions regarding the coaches' habits in formulating strategies were $82.6 \%$ of the coaches took notes using written media, and $17.4 \%$ did not take notes to formulate strategies. The question regarding the coaches' habit of making decisions is that $34.8 \%$ of the coaches' notes using written media, and $65.2 \%$ do not take notes. Meanwhile, the results of the questions regarding coaches' habits in evaluating matches were $87 \%$ of coaches evaluating matches based on notes in written media, and $13 \%$ of coaches did not evaluate based on notes. The coach has reasoned when developing strategies, tactics, and evaluations using written media because it can have an archive of player performance and can make it easier for the coach to deliver the material. Meanwhile, coaches who do not make notes because they are more suitable are only based on the coach's views or experiences during the match.

The game of football has evolved along with the development of computer systems that have allowed a deeper understanding of the phenomenon of performance [29]. The use of statistical data in football requires the help of tools or media that can assist the coach in recording events during the match. The use of statistical data recording media can be used to measure players' performances, team balance, and opponent weaknesses [30]. The absence of tools has made the coach not to use and collect statistical data as a description of the performance of players and teams. Paper media is the coaches' choice for collecting statistical data. Paper media with manual writing is a simple medium that can be an alternative to collecting players and team statistical data. However, the use of paper media is less efficient because paper media has disadvantages such as tearing, flammability, and not being resistant to moisture.

Based on research, $73.9 \%$ of coaches recorded match statistical data without using tools. The absence of tools that can assist coaches in recording statistical data is the use of statistical data recording tools based on android. The use of android is not only flexible and easy to use because the android system is supported by a multi-tasking system, users can access the internet and access applications simultaneously [31]. The results showed that all coaches agreed with recording match statistical data using the android application. Android applications have many advantages compared to writing on manual paper. The selection of an Android-based statistical application will be cheaper than any software abroad. The use of android operations as a tool for recording statistical data will be easier and have more accurate results.

\section{CONCLUSION}

Based on the results of the research and discussion above, it can be concluded that the use of football statistics data cannot be optimized. The use of statistical data that is not optimal is due to the absence of tools, coaches are more confident in their intuition when making decisions, and statistical data are not familiar to coaches. The coach in determining strategies, tactics, and evaluating matches are still limited to using handwritten media. The use of media notes in the form of writing shows that the tools for recording football statistical data have not been able to reach coaches so that the use of statistical data has not been optimal

\section{REFERENCES}

[1] McHale, I. G., Scarf, P. A., \& Folker, D. E. (2012). On the Developmen of a Soccer Player Performance Rating System for the English Premier League. Interfaces, 42(4), 339-351. doi:10.1287/inte.1110.0589

[2] [2] Albert, J. \& Koning, R.H. (2007). Statistical thinking in sport. Boca Raton: Taylor \& Francis Group, LLC.

[3] [3] Lasfeto, D. B. Nurhayati, O. D. (2008). Analisis statistika deskriptif menggunakan MATLAB. Yogyakarta: Graha Ilmu

[4] [4] Moura, F. A., Martins, L. E. B., dan Cunha, S. A. (2013). Analysis of football game-related statistics using multivariate techniques. Journal of Sports Sciences, 2013

[5] [5] McLean, S., Salmon, P. M., Gorman, A. D., Read, G. J. M., \& Solomon, C. (2017). What's in a game? A systems approach to enhancing performance analysis in football. PLOS ONE, 12(2), e0172565. doi:10.1371/journal.pone.0172565

[6] [6] McHale, I. G., \& Szczepański, Ł. (2013). A mixed effects model for identifying goal scoring ability of footballers. Journal of the Royal Statistical Society: Series A (Statistics in Society), 177(2), 397-417. doi:10.1111/rssa.12015

[7] [7] Severini, T.A. (2015). Analytic metods in sport. Boca Raton: Taylor \& Francis Group, LLC.

[8] [8] Liu, H., Gomez, M.-Á., Lago-Peñas, C., \& Sampaio, J. (2015) Match statistics related to winning in the group stage of 2014 Brazil FIFA World Cup. Journal of Sports Sciences, 33(12), 1205-1213.

[9] [9] Liu, H., Gómez, M.-A., Gonçalves, B., \& Sampaio, J. (2015). Technical performance and match-to-match variation in elite football teams. Journal of Sports Sciences, 34(6), 509-518. doi:10.1080/02640414.2015.1117121

[10] [10] Wright, C., Atkins, S., \& Jones, B. (2012). An analysis of elite coaches' engagement with performance analysis services (match, notational analysis and technique analysis). International Journal of Performance Analysis in Sport, 12(2), 436-451. doi:10.1080/24748668.2012.11868609

[11] [11] Drust, B., \& Green, M. (2013). Science and football: evaluating the influence of science on performance. Journal of Sports Sciences, 31(13), 1377-1382. doi:10.1080/02640414.2013.828544

[12] [12] Travassos, B., Davids, K., Araújo, D., \& Esteves, T. P. (2013). Performance analysis in team sports: Advances from an Ecological Dynamics approach. International Journal of Performance Analysis in Sport, 13(1), 83-95. doi:10.1080/24748668.2013.11868633

[13] [13] Glenniza, D. (25 Desember 2016). Mengenal istilah-istilah statistik di sepakbola. Panditfootball.com

[14] [14] Christopher, C., Williams, A. M., \& Reilly, T. (2007). Handbook of soccer match analysis: A systematic approach. New York: Routledge

[15] [15] Djoko Pekik Irianto. (2002). "Dasar Kepelatihan Olahraga". Diktat. FIK UNY.

[16] [16] Gómez, M. A., Gómez-Lopez, M., Lago, C., \& Sampaio, J. (2012). Effects of game location and final outcome on game-related statistics in each zone of the pitch in professional football. European Journal of Sport Science, 12(5), 393-398. doi:10.1080/17461391.2011.566373

[17] [17] Sugiyono. (2019). Metode Penelitian Pendidikan (Kuantitatif, Kualitatif, Kombinasi, RnD dan penelitian Pendidikan) (3rd ed.). Alfabeta.

[18] [18] Dhanurwindo, dkk. (2017). Kurikulum Pembinaan Sepakbola Indonesia. Jakarta: PSSI

[19] [19] Gould, D., Collins, K., Lauer, L., \& Chung, Y. (2007). Coaching Life Skills through Football: A Study of Award Winning High School Coaches. Journal of Applied Sport Psychology, 19(1), 16-37. doi:10.1080/10413200601113786 
[20] [20] Link, D. (2018). Data Analytics in Professional Soccer. Munich Springer Vieweg

[21] [21] Carpita, M., Sandri, M., Simonetto, A., \& Zuccolotto, P. (2015). Discovering the Drivers of Football Match Outcomes with Data Mining Quality Technology \& Quantitative Management, 12(4), 561-577. doi:10.1080/16843703.2015.11673436

[22] [22] Yue, Z., Broich, H., \& Mester, J. (2014). Statistical Analysis for the Soccer Matches of the First Bundesliga. International Journal of Sports Science \& Coaching, 9(3), 553-560. doi:10.1260/1747-9541.9.3.553

[23] [23] Reilly T, Drust B, Clarke N. (2008). Muscle fatigue during football match-play. Sports Med 2008; 38, 357-367. doi:10.2165/00007256200838050-00001

[24] [24] Lago-Peñas, C., \& Gómez-López, M. (2014). How Important is it to Score a Goal? The Influence of the Scoreline on Match Performance in Elite Soccer. Perceptual and Motor Skills, 119(3), 774-784. doi:10.2466/23.27.pms.119c32z1

[25] [25] Castellano, J. Casamichana, D. Lago, C. (2012). The Use of Match Statistics that Discriminate Between Successful and Unsuccessful Soccer Teams. Journal of Human Kinetics volume 31/2012, 139-147
[26] [26] Duch, J., Waitzman, J. S., dan Amaral, L. A. N. (2010). Quantifying the Performance of Individual Players in a Team Activity. Journal Plos One, June 2010, Volume 5, Issue 6

[27] [27] Liu, H., Hopkins, W. G., \& Gómez, M.-A. (2015). Modelling relationships between match events and match outcome in elite football. European Journal of Sport Science, 16(5), 516-525. doi:10.1080/17461391.2015.1042527

[28] [28] Kurniawan R.D. \& Agus H. (2018). Efektivitas Permainan Peserta Indonesian Basketball League (Ibl) 2017 / 2018 Pada Pertandingan Semifinal Dan Final (Berdasarkan Statistik Pertandingan). Jurnal Prestasi Olahraga, Vol 1, No 4, 2018

[29] [29] Sarmento, H., Marcelino, R., Anguera, M. T., CampaniÇo, J., Matos, N., \& LeitÃo, J. C. (2014). Match analysis in football: a systematic review. Journal of Sports Sciences, 32(20), 1831-1843. doi:10.1080/02640414.2014.898852

[30] [30] Schumaker, R.P., Solieman, O.K., \& Chen, H. (2010). Sport Data Mining. New York: Spinger.

[31] [31] Antoni, M. S. dan Suharjana, S. (2019). Pengembangan Aplikasi Rockport Walking Fitness Test Berbasis Android. Tesis, tidak diterbitkan Universitas Negeri Yogyakarta, Yogyakarta. 